\title{
Nitrogen feedbacks increase future terrestrial ecosystem carbon uptake in an individual-based dynamic vegetation model
}

\author{
D. Wårlind ${ }^{1}$, B. Smith ${ }^{1}$, T. Hickler ${ }^{2,3}$, and A. Arneth ${ }^{4}$ \\ ${ }^{1}$ Department of Physical Geography and Ecosystem Science, Lund University, Sölvegatan 12, 22362 Lund, Sweden \\ ${ }^{2}$ Biodiversity and Climate Research Centre (BiK-F), Senckenberganlage 25, 60325 Frankfurt am Main, Germany \\ ${ }^{3}$ Institute of Physical Geography, Goethe-University, Altenhöferallee 1, 60438 Frankfurt am Main, Germany \\ ${ }^{4}$ Karlsruhe Institute of Technology, Institute of Meteorology and Climate Research/Atmospheric Environmental Research, \\ 82467 Garmisch-Partenkirchen, Germany
}

Correspondence to: D. Wårlind (david.warlind@csiro.au)

Received: 19 September 2013 - Published in Biogeosciences Discuss.: 5 January 2014

Revised: 23 September 2014 - Accepted: 29 September 2014 - Published: 13 November 2014

\begin{abstract}
Recently a considerable amount of effort has been put into quantifying how interactions of the carbon and nitrogen cycle affect future terrestrial carbon sinks. Dynamic vegetation models, representing the nitrogen cycle with varying degree of complexity, have shown diverging constraints of nitrogen dynamics on future carbon sequestration. In this study, we use LPJ-GUESS, a dynamic vegetation model employing a detailed individual- and patch-based representation of vegetation dynamics, to evaluate how population dynamics and resource competition between plant functional types, combined with nitrogen dynamics, have influenced the terrestrial carbon storage in the past and to investigate how terrestrial carbon and nitrogen dynamics might change in the future (1850 to 2100; one representative "business-as-usual" climate scenario). Single-factor model experiments of $\mathrm{CO}_{2}$ fertilisation and climate change show generally similar directions of the responses of $\mathrm{C}-\mathrm{N}$ interactions, compared to the $\mathrm{C}$-only version of the model as documented in previous studies using other global models. Under an RCP 8.5 scenario, nitrogen limitation suppresses potential $\mathrm{CO}_{2}$ fertilisation, reducing the cumulative net ecosystem carbon uptake between 1850 and 2100 by $61 \%$, and soil warming-induced increase in nitrogen mineralisation reduces terrestrial carbon loss by $31 \%$. When environmental changes are considered conjointly, carbon sequestration is limited by nitrogen dynamics up to the present. However, during the 21 st century, nitrogen dynamics induce a net increase in carbon sequestration, resulting in an overall larger carbon uptake of $17 \%$ over the full period. This contrasts with previous results with
\end{abstract}

other global models that have shown an 8 to $37 \%$ decrease in carbon uptake relative to modern baseline conditions. Implications for the plausibility of earlier projections of future terrestrial $\mathrm{C}$ dynamics based on C-only models are discussed.

\section{Introduction}

The nature of future climate change will depend on anthropogenic emissions of $\mathrm{CO}_{2}$, and climate and $\mathrm{CO}_{2}$-mediated feedbacks through carbon (C) cycling in both terrestrial ecosystems and oceans (Friedlingstein et al., 2006; Heimann and Reichstein, 2008; Sitch et al., 2008; Arneth et al., 2010a; Raupach, 2011). Terrestrial ecosystems currently remove about a quarter of the anthropogenic $\mathrm{CO}_{2}$ fossil-fuel and land-use change emissions from the atmosphere (Schulze, 2006; Canadell et al., 2007), but attribution of this sink for atmospheric carbon to underlying mechanisms and the regions where it occurs is a challenging task. As a consequence, projections of how the $\mathrm{C}$ cycle may evolve under a future rapidly changing climate diverge widely (Raupach, 2011; Ahlstrom et al., 2012; Stocker et al., 2013). Considerable attention has focused in recent years on whether and how interactions of the $\mathrm{C}$ and nitrogen $(\mathrm{N})$ cycles will affect future terrestrial ecosystem $\mathrm{C}$ balance. Until relatively recently these interactions were not considered in models of the global $\mathrm{C}$ cycle, although in many ecosystems $\mathrm{N}$ is regarded as a limiting factor, controlling $\mathrm{C}$ uptake in present-day environments (Vitousek and Howarth, 1991; Galloway et al., 2008; Arneth et 
al., 2010a). Full-scale ecosystem manipulation studies such as free air $\mathrm{CO}_{2}$ enrichment (FACE) experiments, that assess ecosystem responses to a step-increase in atmospheric $\left[\mathrm{CO}_{2}\right]$, have in certain cases exhibited an initial enhancement in $\mathrm{C}$ uptake under elevated $\left[\mathrm{CO}_{2}\right]$ that declines over time, arguably due to progressive $\mathrm{N}$ limitation (Luo et al., 2004), abating the initial $\mathrm{CO}_{2}$ fertilisation of plant production (Norby et al., 2010). However, other FACE experiments have shown a sustained enhancement of $\mathrm{C}$ uptake in conjunction with $\mathrm{CO}_{2}$ enrichment (Finzi et al., 2007; Carthy et al., 2010). Soil-warming experiments have shown that an initial decrease in soil $\mathrm{C}$ pools due to increased heterotrophic respiration was almost offset by an increase in soil $\mathrm{N}$ mineralisation, increasing plant $\mathrm{C}$ uptake capacity (Melillo et al., 2011). Still, relatively few full-scale multi-factorial ecosystem experiments have been conducted to date, and these have been of limited duration, leaving the effects of interactions among drivers of, and on, future change in climate, atmospheric $\mathrm{CO}_{2}$ and other environmental changes such as atmospheric $\mathrm{N}$ deposition unclear (Beier, 2004; Leuzinger et al., 2011).

A few, recent, simulation experiments using dynamic vegetation models (DVMs) have begun to address the magnitude of an effect of $\mathrm{C}-\mathrm{N}$ interactions on historical and future terrestrial ecosystem $\mathrm{C}$ cycling. These studies agree in principle on the main involved processes, namely that future $\mathrm{CO}_{2}$ fertilisation of global photosynthesis can be reduced by limitations imposed through $\mathrm{N}$ availability, and that warmer temperatures can result in increased soil $\mathrm{N}$ mineralisation, increasing $\mathrm{C}$ uptake (Sokolov et al., 2008; Fisher et al., 2010a; Zaehle et al., 2010; Goll et al., 2012). However, the relative magnitudes of these competing processes diverge between model studies. If these antagonistic interactions result in a reduction in terrestrial $\mathrm{C}$ storage under future climate forcing (Sokolov et al., 2008; Thornton et al., 2009; Arneth et al., 2010a; Zaehle et al., 2010) the net feedback effect will be an increased atmospheric load of $\mathrm{CO}_{2}$ leading to increased radiative forcing and accelerated warming (Arneth et al., 2010a; Arora et al., 2013).

The introduction of $\mathrm{N}$ feedbacks will not only alter future land $\mathrm{C}$ storage through its effect on $\mathrm{CO}_{2}$ fertilisation and $\mathrm{N}$ mineralisation, but it will also have downstream effects on higher-order ecosystem interactions like population dynamics and competition between plant functional types (PFTs). As a result, shifts in biome distributions may be expected when $\mathrm{C}-\mathrm{N}$ interactions are taken into account (Smith et al., 2014). In DVMs, biome patterns and ecosystem composition in terms of presence/absence and relative abundance of different PFTs are determined through bioclimatic constraints on the establishment and/or survival of individual PFTs, and through competition between PFTs for resources needed for growth such as light, water and N. Conversely, shifts in vegetation structure will affect $\mathrm{C}$ and $\mathrm{N}$ cycling within ecosystems, by affecting residence times for assimilated $\mathrm{C}$ and $\mathrm{N}$ in plant tissue compartments and, following phenology- and mortality-driven turnover, in the soil. A shift in the abun- dance or density of trees and shrubs, in particular, may be associated with decennial-scale lags in the response of biogeochemical fluxes, as a proportion of "additional" assimilates are allocated to the long-lived woody biomass compartment of the ecosystem. Thus the $\mathrm{C}$ and $\mathrm{N}$ balance simulated by a particular model in response to a perturbation such as a climate change scenario may be expected to depend on the representation of vegetation structural dynamics and the associated feedbacks to ecosystem function. Due to the presence of lags, this dependency may be particularly important over a transient period.

Only a few DVMs explicitly represent differences in age/size structure among individuals within a PFT and canopy structural variation in time as a result of birth, death and growth of individuals (so called demographics) (Moorcroft et al., 2001; Smith et al., 2001, 2014; Fisher et al., 2010b). Demographics allow for the possibility to with greater realism represent the mechanisms underlying competition, their effects on population and community structure, and the resultant feedback to resource uptake, C assimilation and growth (Smith et al., 2001; Wolf et al., 2011). It has been suggested that the representation of demographics is a precondition for the accurate representation of the $\mathrm{C} \mathrm{dy-}$ namics and climate feedbacks in forest and savannah ecosystems (Purves and Pacala, 2008; Fisher et al., 2010b; Wolf et al., 2011). Scheiter and Higgins (2009) showed the importance of simulating individual trees in a savannah ecosystem to be able distinguish between small trees, that are completely consumed in fires, and large trees, that are generally unaffected by fires. A similar result has also been found for simulations with the LPJ-GUESS model, employed in this study, along a climate-transient in sub-Saharan Africa (Arneth et al., 2010b). In particular, the effect of tree-tree interaction and self-thinning is important in savannah ecosystems to potentially allow trees to grow taller in the presence of fire than in the absence of fire. What is more, in forest ecosystems, succession between PFTs can be represented in a realistic manner which is important not only for simulating carbon dynamics after disturbance or when cropland is re-converted into forest, but also for other exchange processes with the atmosphere that are strongly dependent on vegetation composition (Hickler et al., 2004; Arneth et al., 2008; Lindeskog et al., 2013; Smith et al., 2014). Our study employs LPJ-GUESS, which combines process-based representations of ecosystem $\mathrm{C}$ and $\mathrm{N}$ biogeochemistry with an individual- and patch-based representation of vegetation dynamics, similar to "forest gap" models (Bugmann et al., 2001). Smith et al. (2001) showed for 11 vegetation zones encompassing the climate space of Europe that this resulted in a more realistic time-evolution of vegetation structure and PFT composition compared with the more generalised, area-based vegetation dynamics scheme of LPJ, a representative firstgeneration DVM (Sitch et al., 2003). Vegetation structure, composition and dynamics simulated by the model have been compared with observations for biomes including boreal and 
temperate forest, savannahs, grasslands and Arctic tundra, generally showing favourable performance (e.g. Hickler et al., 2004, 2012; Hély et al., 2006; Tang et al., 2012; Lindeskog et al., 2013; Zhang et al., 2013; Smith et al., 2014).

Smith et al. (2014) provided a detailed description of the N-cycle implementation in LPJ-GUESS, evaluating the model against a range of observational data sets and exploring modelled responses to drivers in stylised global-change experiments. One such experiment quantified changes in terrestrial biosphere $\mathrm{N}$ and $\mathrm{C}$ storage under a representative concentration pathway (RCP) 8.5 (business-as-usual) future climate projection, noting that LPJ-GUESS, in contrast to other models (Sokolov et al., 2008, Fisher et al., 2010a, Zaehle et al., 2010a, Goll et al., 2012), predicts a net increase in biosphere $\mathrm{C}$-storage when $\mathrm{N}$-limitation is taken into account. In this study, we expand on the analysis of Smith et al. (2014) by examining regional patterns of response of $\mathrm{N}-\mathrm{C}$ biogeochemistry, potential vegetation composition and structure, and their contrasting underlying mechanisms, that combine to produce the above-mentioned aggregate global result. To disaggregate the contributions of individual drivers to overall simulated responses, regionally and globally, we additionally perform factorial simulations independently varying individual drivers (climate, atmospheric $\mathrm{CO}_{2}$ concentration and $\mathrm{N}$ deposition). We also discuss and demonstrate the role that the detailed individual- and patch-based representation of vegetation dynamics in LPJ-GUESS, unique among models so far used to simulate effects of $\mathrm{N}$-cycle feedbacks on $\mathrm{C}$ biogeochemistry at global scale, may have in explaining the contrasting responses predicted by our model compared to previous DVM studies.

\section{Methods}

Global patterns of natural ecosystem $\mathrm{C}$ and $\mathrm{N}$ fluxes and pool sizes were simulated with LPJ-GUESS (Smith et al., $2001,2014)$ a process-based model of vegetation dynamics and biogeochemistry that incorporates a detailed, individualand patch-based representation of tree population dynamics and resource competition (Smith et al., 2001). The competitive strength of a PFT is determined by its bioclimatic limits, phenology, allometry, shade tolerance, specific resource uptake capacity, mortality, and establishment under changing stand structure and environment. For each location, the model simulates a set of replicate patches where PFT agecohorts (hereinafter "cohorts") compete for light, water and soil available N. A patch represents the area over which one large adult tree would influence its neighbours, a concept commonly used in forest gap models (Bugmann, 2001). The patch replicates account for stochastic processes associated with establishment, mortality and disturbance. Disturbance is represented by fire (Sitch et al., 2003) and by a mean return interval for generic, patch-destroying disturbances, representing, for example, windstorms and insect-attacks. A lo- cation's ecosystem state and material fluxes are derived as the average over the replicate patches, representing a landscape average. Canopy physiology and gas exchange, plant carbon allocation and soil hydrology follow the approach of the LPJ model (Sitch et al. 2003).

The newly implemented C-N interactions in LPJ-GUESS are described in detail in Smith et al. (2014), but will be briefly covered here. The $\mathrm{N}$ cycle in LPJ-GUESS simulates dynamically the build-up of a soil mineral $\mathrm{N}$ pool through mineralisation of soil organic matter (SOM), atmospheric $\mathrm{N}$ deposition and biological $\mathrm{N}$ fixation. Biological $\mathrm{N}$ fixation is estimated annually through an empirical correlation between $\mathrm{N}$ fixation and evapotranspiration (Cleveland et al., 1999). $\mathrm{N}$ deposition is an external input, provided here by the ACCMIP global data set (Lamarque et al., 2010, 2011), providing monthly wet and dry $\mathrm{N}$ deposition that varies decadally. In the presence of a snow pack $\mathrm{N}$ deposition is stored and released to the soil mineral $\mathrm{N}$ pool in proportion to snow melt. SOM decomposition, respiration, leaching and transfer of SOM between 11 pools of contrasting residence time are modelled using a scheme adopted from the CENTURY model (Parton et al., 1993; Comins and McMurtrie, 1993; Kirschbaum and Paul, 2002; Parton et al., 2010). In this approach, $\mathrm{N}$ mineralisation or immobilisation, results from the transfer of SOM between pools, maintaining mass balance and prescribed or computed $\mathrm{C}: \mathrm{N}$ ratios of the donor and receiver pool. $\mathrm{N}$ mineralisation augments and immobilisation depletes the plant-available pool of mineral $\mathrm{N}$. The rate of decomposition is affected by a temperature and moisture modifier and the size of the mineral $\mathrm{N}$ pool if immobilisation is the dominant process in the SOM system. The daily plant $\mathrm{N}$ demand is driven by optimal leaf $\mathrm{N}$ content required for photosynthesis, computed based on the optimisation of carboxylation capacity of Rubisco (Haxeltine and Prentice, 1996a), and leaf $\mathrm{N}$ not associated with photosynthesis, connected directly to daily leaf $\mathrm{C}$ content. Maximum $\mathrm{C}$ content of leaves and roots is determined annually, daily $\mathrm{C}$ content following the phenological development during the year. The $\mathrm{N}$ demand of other compartments of the plant and their $\mathrm{N}$ concentrations are proportional in relationship to each other and the optimal leaf $\mathrm{N}$ content (Friend et al., 1997; White et al., 2000; Zaehle and Friend, 2010). The daily $\mathrm{N}$ uptake capacity, which ideally meets the calculated demand, is directly proportional to plant fine root $\mathrm{C}$ mass (Rothstein et al., 2000; Macduff et al., 2002), but with additional constrains imposed by soil mineral $\mathrm{N}$ pool, plant $\mathrm{N}$ status, and soil temperature (Zaehle and Friend, 2010). If $\mathrm{N}$ uptake capacity cannot meet the demand, $\mathrm{N}$ from a vegetation storage pool is used. If there still is a shortage, the plant is considered to be under $\mathrm{N}$ stress and the carboxylation capacity is reduced accordingly, with spill-over effects on leaf and non-green tissue $\mathrm{N}$ content. The plant $\mathrm{N}$ storage pool is filled during the previous year with retranslocated $\mathrm{N}$ from shedding of leaves and fine roots, accompanied by a set fraction of total $\mathrm{N}$ uptake. If storage capacity is exceeded, less $\mathrm{N}$ is retranslocated and 
Table 1. Modelled C sequestration [PgC] for periods 1850 to 2000 and 1850 to 2100 with LPJ-GUESS and four additional C-N models with $\%$ difference between $\mathrm{C}$-only and $\mathrm{C}-\mathrm{N}$ versions.

\begin{tabular}{lrrrrrrrr}
\hline \multirow{2}{*}{ Model $^{1}$} & \multicolumn{3}{c}{1850 to 2000} & & \multicolumn{3}{c}{1850 to 2100 } \\
\cline { 2 - 3 } \cline { 7 - 9 } & C-only & C-N & \% diff & & C-only & C-N & $\%$ diff \\
\hline LPJ-GUESS & 76 & 45 & -41 & & 317 & 372 & 17 \\
TEM & 90 & 80 & -11 & & 332 & 242 & -27 \\
O-CN & 108 & 83 & -23 & & 388 & 244 & -37 \\
FUN & 85 & 78 & -8 & & 288 & 264 & -8 \\
JSBACH & 158 & 150 & -5 & & 550 & 479 & -13 \\
\hline
\end{tabular}

${ }^{1}$ LPJ-GUESS - this paper; TEM - Sokolov et al. (2008); O-CN - Zaehle et al. (2010); FUN Fisher et al. (2010a); JSBACH - Goll et al. (2012).

the shed leaves and fine roots have a higher $\mathrm{N}$ concentration. Such a situation represents a N-rich environment, in which $\mathrm{N}$ uptake from the soil mineral $\mathrm{N}$ pool is more energy costefficient for plants compared to retranslocation (Wright and Westoby, 2003; Fisher et al., 2010a). If the daily total $\mathrm{N}$ demand/uptake capacity from all PFT cohorts within a single patch cannot be met by the soil mineral $\mathrm{N}$ pool, the cohorts have to compete for the resources, where the competitiveness of the cohorts is determined by their fine-root $\mathrm{C}$ mass and its vertical distribution. $\mathrm{N}$ stress consequently also affects the $\mathrm{C}$ allocation fraction between shoots and fine roots, $\mathrm{N}$-stressed cohorts allocating more $\mathrm{C}$ to fine roots, compared to shoots, as a strategy to increase $\mathrm{N}$ uptake capacity and competitiveness compared to other cohorts. The C-only version of LPJ-GUESS employed in this study uses the same CENTURY-based SOM dynamics scheme, described above, but with no $\mathrm{N}$ limitation on decay rates and no $\mathrm{N}$ limitation on photosynthesis and plant growth.

The $\mathrm{N}$ cycle in LPJ-GUESS has been evaluated and shown to simulate $\mathrm{C}$ and $\mathrm{N}$ fluxes observed at a range of field sites (Fleischer et al., 2014; Smith et al., 2014), at FACE experiments simulating future climate change scenarios (De Kauwe et al., 2013), and to agree well with current best-estimates of global C and N pools and fluxes (Smith et al., 2014). Here, we examine the $\mathrm{C}-\mathrm{N}$ interactions and feedbacks on potential natural vegetation in response to future climate, $\mathrm{CO}_{2}$ and $\mathrm{N}$ deposition forcing. LPJ-GUESS was forced with output from a "business as usual" future climate simulation with the MPI-ESM-LR general circulation model (GCM) under RCP 8.5 with prescribed atmospheric $\left[\mathrm{CO}_{2}\right]$ forcing (Giorgetta et al., 2013). MPI-ESM-LR results were simulated to lead to middle-range $\mathrm{C}$ sequestration in a recent comparison among GCMs using the C-only version of LPJ-GUESS (Ahlstrom et al., 2012). CRU TS 3.0 1961-1990 climatologies (Mitchell and Jones, 2005) were used to bias-correct the GCM climate fields, which were interpolated spatially to the CRU grid $\left(0.5^{\circ} \times 0.5^{\circ}\right.$ resolution). Historical (Lamarque et al., 2010) and future (Lamarque et al., 2011) RCP $8.5 \mathrm{~N}$ deposition forcings were from the CAM model (Gent et al., 2010). Data for the initial 500-year model spin-up phase were derived by detrending 1850-1879 climate. Constant atmospheric $\left[\mathrm{CO}_{2}\right]$ and $\mathrm{N}$ deposition at 1850 levels were assumed. After spin-up, historical climate data, atmospheric $\left[\mathrm{CO}_{2}\right]$ and $\mathrm{N}$ deposition were used, until 2006 when the RCP 8.5 scenario period starts and runs until 2100 . The simulations were performed with 30 replicate patches per modelled grid cell, sufficient to represent the regional vegetation with negligible stochastic variation. Four different model setups where used during the study. In ALL, climate change (temperature, precipitation and radiation), $\mathrm{CO}_{2}$ and $\mathrm{N}$ deposition conjointly affected simulated processes. In the single-factor simulations either climate change (CLIM), atmospheric $\left[\mathrm{CO}_{2}\right](\mathrm{CO} 2)$ or $\mathrm{N}$ deposition (NDEP) were varied while other forcings were held constant at the same levels as in the spin-up protocol.

\section{Results}

Over the historical time period (1850-2000), total C sequestration in terrestrial ecosystems in the C-only version of LPJGUESS exceeded $\mathrm{C}$ sequestration in the $\mathrm{C}-\mathrm{N}$ version by about one-third (Table 1 and Fig. 1a). A reduced past-topresent cumulative $\mathrm{C}$ sequestration in $\mathrm{C}-\mathrm{N}$ versions of terrestrial models seems to emerge as a robust pattern that has also been found in previous studies (Table 1), even though the relative importance of $\mathrm{N}-\mathrm{C}$ interactions in LPJ-GUESS is comparatively large compared with other models. The differences imply $\mathrm{N}$ limitation of $\mathrm{C}$ cycling over this period, but indirect effects (e.g. initial conditions) vary as the $\mathrm{C}$-only and $\mathrm{C}-\mathrm{N}$ configurations of the model differ in PFT composition and $\mathrm{C}$ pool sizes after the spin-up (Appendix Table A2). During the 21 st century, warming induces an increase in soil $\mathrm{N}$ mineralisation, which in the climate change-only experiment reduces $\mathrm{C}$ losses notably, while availability of $\mathrm{N}$ substantially limits photosynthetic $\mathrm{C}$ uptake in the $\mathrm{CO}_{2}$-only experiment (Fig. 1 and Table A1). Comparable to what is being observed for the historical period, a robust pattern seems to emerge such that the direction of individual process responses to $\mathrm{C}-\mathrm{N}$ interactions in factorial model experiments is similar (Zaehle et al., 2010). However, when environmental changes are considered conjointly, the net response of the 

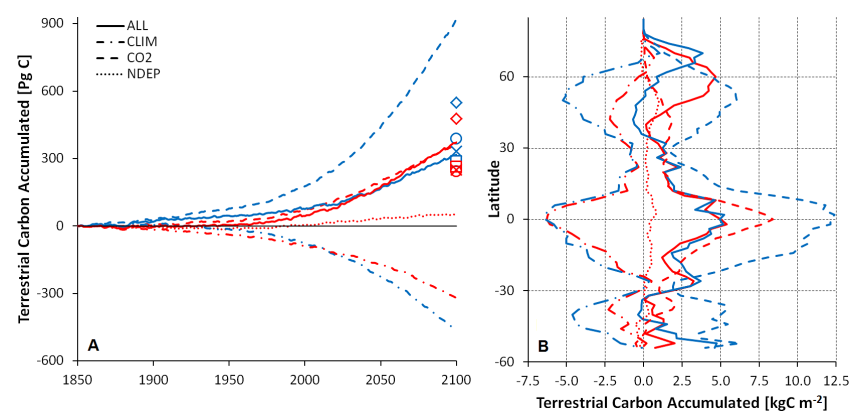

Figure 1. Cumulative terrestrial C sequestrated between 1850 and 2100 (a) simulated with historical and future change in climate (CLIM), atmospheric $\left[\mathrm{CO}_{2}\right]$ (CO2), $\mathrm{N}$ deposition (NDEP) alone, and all together (ALL). Other model results are for TEM (X), O$\mathrm{CN}(\mathrm{O})$, FUN $(\square)$, and JSBACH $(\diamond)$. Latitudinal accumulated terrestrial $\mathrm{C}$ sequestration between 2000 and 2100 (b). Blue lines are $\mathrm{C}$-only version and red lines are $\mathrm{C}-\mathrm{N}$ version.

global terrestrial $\mathrm{C}$ sink differs between models. In the case of LPJ-GUESS, total C accumulated from 1850-2100 in the $\mathrm{C}-\mathrm{N}$ version exceeds the $\mathrm{C}$-only version by $17 \%$, while previously published model results have generally found a decline of variable magnitude after accounting for $\mathrm{C}-\mathrm{N}$ interactions (Table 1, Table A1 and Fig. 1a).

The simulated shift to higher $\mathrm{C}$ sequestration with $\mathrm{N}$ dynamics during the 21 st century is mainly due to $\mathrm{C}-\mathrm{N}$ interactions in the mid/high latitudes (Figs. $1 \mathrm{~b}$ and 2). Here, the climate change-only experiment induced an increase in soil $\mathrm{N}$ availability to plants, reducing net $\mathrm{C}$ losses from ecosystems, whereas the $\mathrm{CO}_{2}$-only experiments show a reduction in $\mathrm{C}$ uptake during $\mathrm{CO}_{2}$ fertilisation under $\mathrm{N}$ limitation. These effects increase with latitude (Fig. 1b), a pattern also seen in earlier model studies (Thornton et al., 2007; Jain et al., 2009; Zaehle et al., 2010). When environmental changes are considered conjointly, the small degree of $\mathrm{N}$ limitation seen in the $\mathrm{CO}_{2}$-only experiment in the lower latitudes vanishes. In the mid/high latitudes the interaction of soil warming and $\mathrm{CO}_{2}$ fertilisation results in a higher $\mathrm{C}$ sequestration when $\mathrm{C}-\mathrm{N}$ interactions are included. For the northernmost latitudes the $\mathrm{N}$ limitation persists and the $\mathrm{C}$ sequestration in the $\mathrm{C}-\mathrm{N}$ versions is lower than in the C-only version (Figs. $1 \mathrm{~b}$ and 2).

Changes in $\mathrm{C}$ pools when considering $\mathrm{C}-\mathrm{N}$ interactions, climate change and changes in atmospheric $\left[\mathrm{CO}_{2}\right]$ cannot be explained by physiological process responses alone, but also depend on adjustments in vegetation composition and structure. Representative examples of the vegetation evolution simulated for different biomes of the world are shown in Figs. 3 and 4. These figures reveal that large-scale biome shifts are influenced by $\mathrm{N}$ dynamics mainly in colder regions, e.g. the transition from ecosystems dominated by grass to needleleaf biomes in northern Canada, which is suppressed by $\mathrm{N}$ dynamics (Figs. 3 and 4 central panels and location a). For the northernmost latitudes of Siberia, N limitation changes both the initial state of biome distribution

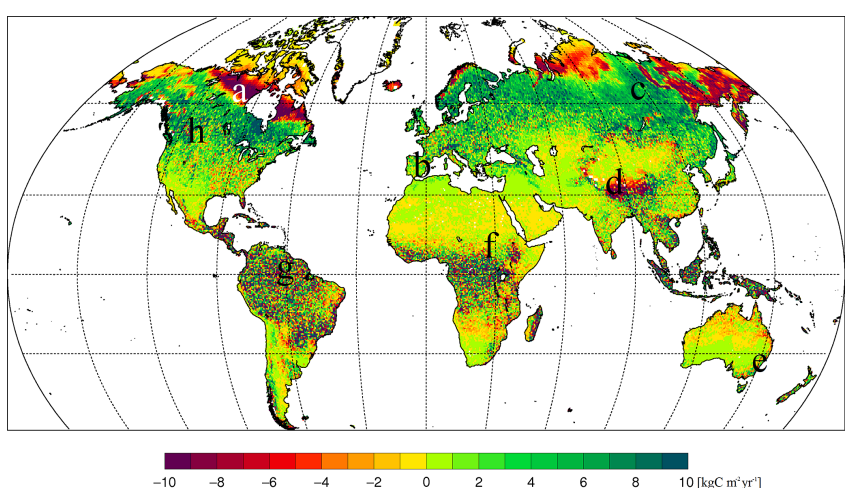

Figure 2. Simulated terrestrial $\mathrm{C}$ sequestration differences between the C-only and $\mathrm{C}-\mathrm{N}$ version for the 21 st century (calculated as $\mathrm{C}-\mathrm{N}$ total pool change for 1990-2000 to 2090-2100 subtracted by Conly total pool change for 1990-2000 to 2090-2100). Negative values indicating a larger cumulative uptake for the $\mathrm{C}$-only version than for the $\mathrm{C}-\mathrm{N}$ version. Letters $\mathrm{a}-\mathrm{h}$ indicate regions detailed in Figs. 3 and 4 .

and $\mathrm{C}$ pool sizes, but also the competitive strength of boreal conifers relative to understorey grasses (which in the model may be taken to represent understorey vegetation in general), influencing the $\mathrm{C}$ sequestration in long-lived woody tissue (Figs. 3 and 4, central panels and location c). The latitudinal influences are clear in the highlighted changes, where locations in warmer climates experience less influence of $\mathrm{N}$ dynamics (Figs. 3 and 4 locations b, e, f, g), whereas locations in colder climates experience a lower fractional representation of woody PFTs and an inability of newly established PFT to compete for $\mathrm{N}$ resource with existing vegetation under $\mathrm{N}$ limitation (Figs. 3 and 4, locations a, c, d, h).

\section{Discussion}

Even though two versions of the same model are compared here, with respect to their interactions with a changing environment, a direct comparison between the C-only and $\mathrm{C}-\mathrm{N}$ version of the model is complicated by a number of ecosystem-scale feedbacks that are introduced in the $\mathrm{C}-\mathrm{N}$ version, causing differences in the equilibrium state after the spin-up in the C-pool sizes (Table A2) and the PFT distribution (Thornton et al., 2007, 2009). Large differences in $\mathrm{C}$-pool sizes originate from the equilibrium condition with climate and $\mathrm{CO}_{2}$, both in vegetation and soils. For the $\mathrm{C}-\mathrm{N}$ version of the model, the initial state is also in equilibrium with a pre-industrial level of $\mathrm{N}$ deposition. Since this is not included in the C-only version, the initial states are unavoidably different between the two model versions. These differences arising from the spin-up procedure are important also for the transient model experiments: if both versions of the model were to start from the same initial condition, the sudden addition of $\mathrm{N}$ limitations to the $\mathrm{C}-\mathrm{N}$ version when the transient phase of the experiment commences would create 


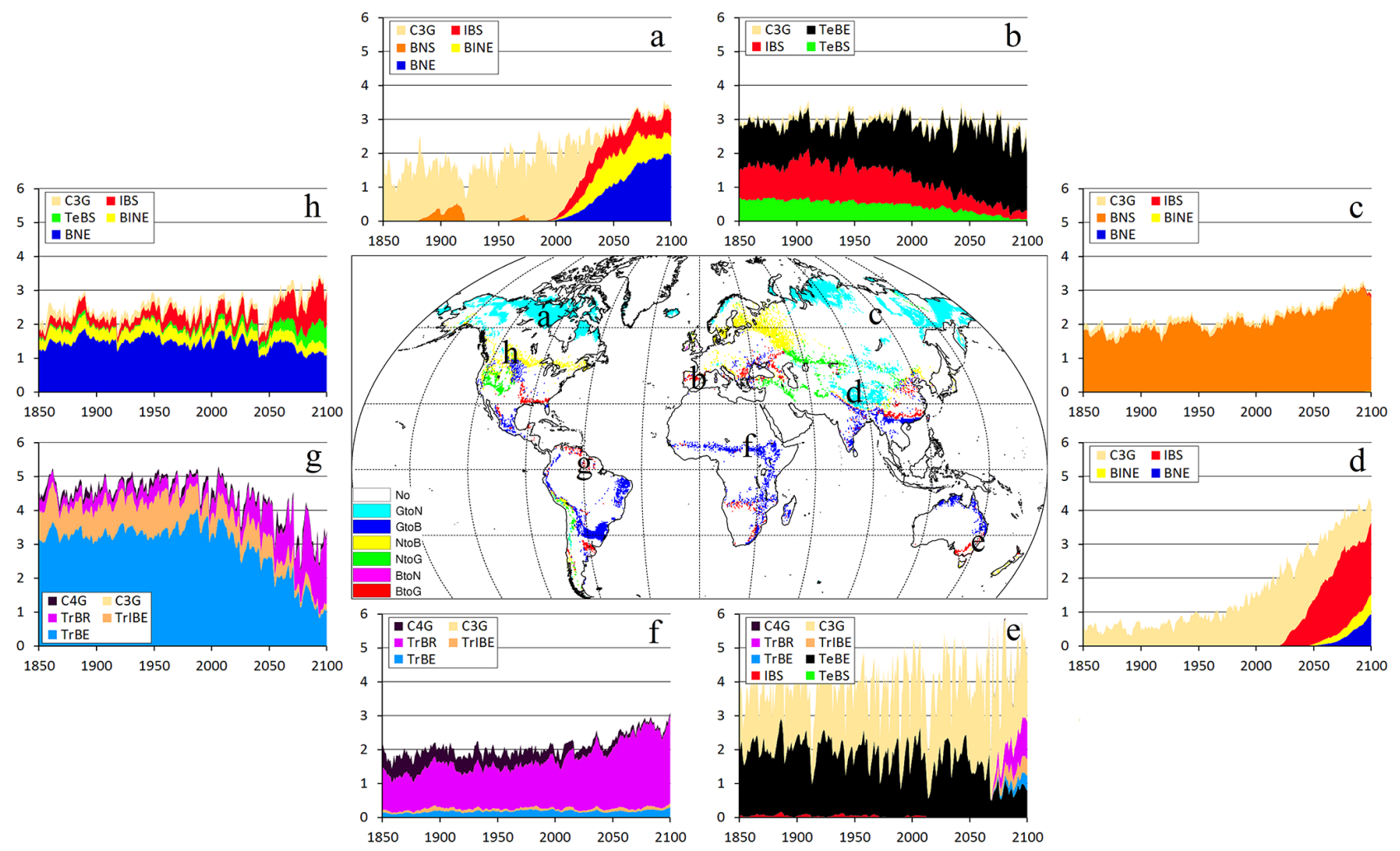

Figure 3. Major biome shift for the C-only version from year 2000-2100 using three broad biome classifications; grass (G), broadleaf (B), and needleleaf $(\mathrm{N})$ dominated. Shifts are denoted in the central panel as biome to biome, e.g. shift from grass to broadleaf dominated is denoted as "GtoB". "No" implies no major shift of biome over the period. The panels (a-f) show changes of leaf area index $\left[\mathrm{m}^{2} \mathrm{~m}^{-2}\right]$ over the simulated simulation period for grid cells in the eight regions from Fig. 2. BNE = boreal needleleaved evergreen tree; BINE $=$ boreal shade-intolerant needleleaved evergreen tree; BNS = boreal needleleaved summergreen tree; TeBS = temperate broadleaved summergreen tree; IBS = temperate shade-intolerant broadleaved summergreen tree; TeBE $=$ temperate broadleaved evergreen tree; $\mathrm{TrBE}=$ tropical broadleaved evergreen tree; $\mathrm{TrIBE}=$ tropical shade-intolerant broadleaved evergreen tree; $\mathrm{TrBR}=$ tropical broadleaved raingreen tree; $\mathrm{C} 3 \mathrm{G}$ $=\mathrm{C}_{3}$ (cool) grass; $\mathrm{C} 4 \mathrm{G}=\mathrm{C}_{4}$ (warm) grass.

an artificial offset and/or trend to the simulations. Such a response would render it impossible to separate what is driving the shift in vegetation structure and $\mathrm{C}$ sequestration. Either it could be the model converting to equilibrium for the present environmental conditions, or it could be the change in environmental conditions over time.

Considering the joint impacts of environmental change, the hindcasts simulated with LPJ-GUESS from pre-industrial times up to the end of the 20th century are principally comparable to what has been found in other model studies (Sokolov et al., 2008; Fisher et al., 2010a; Zaehle et al., 2010; Goll et al., 2012), showing a reduction of global $C$ sequestration when $\mathrm{N}$ dynamics are considered. Compared to these previous studies, our model simulates the lowest amount of $\mathrm{C}$ sequestrated up to the present day and the strongest $\mathrm{N}$ limitation (Table 1). The influence of $\mathrm{N}$ dynamics is most pronounced in the mid/high-latitude cool climates where it reduces the woody component of vegetation in favour of a higher proportion of herbs and grasses. In other words, forests are simulated as sparser, with a more developed un- derstorey, in the $\mathrm{C}-\mathrm{N}$ simulation. As a result, a larger proportion of the general increase in net primary productivity (NPP) seen in mid-latitude areas over the 20th century is allocated to fast-turnover biomass pools (leaves and roots) in the $\mathrm{C}-\mathrm{N}$ simulation, lowering the average residence time of $\mathrm{C}$ in vegetation, and reducing the amount of $\mathrm{C}$ sequestered. The strongest differences between the two model versions are in the sizes of the litter pools. The strong initial $\mathrm{N}$ limitation reduces standing biomass to a considerable degree, and prevents closed canopy in many regions of the mid/high latitudes. As a consequence, the process of self-thinning is not taking place to a similar degree compared with the C-only version of the model, reducing the production of woody litter in conjunction with tree mortality. At present, the model does not include organic $\mathrm{N}$ uptake which has been found to be a potentially significant source of $\mathrm{N}$ for boreal and subArctic vegetation (Näsholm et al., 1998, 2009; Persson et al., 2003; Whiteside et al., 2012). For colder ecosystems, where $\mathrm{N}$ availability is limited due to low $\mathrm{N}$ mineralisation rates, the ability to represent organic $\mathrm{N}$ uptake, conjointly with a 


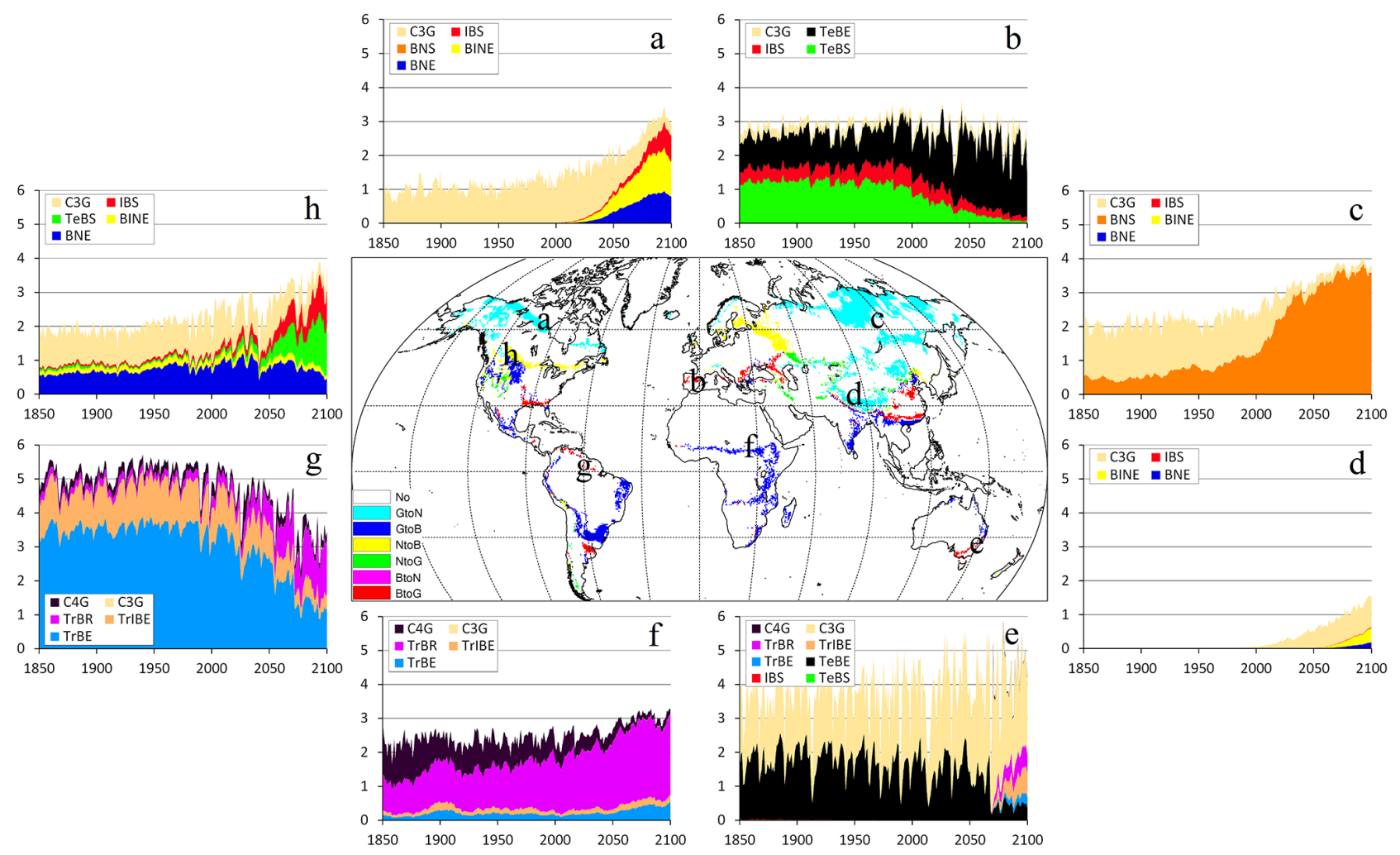

Figure 4. Major biome shift for the C-N version from year 2000-2100, applying the same classification and approach as in Fig. 3. Like in Fig. 3, the global map is accompanied by detailed time-trends for a number of regions identified in Fig. 2.

process-based representation of biological $\mathrm{N}$ fixation, seems an important step for future development of $\mathrm{N}-\mathrm{C}$ models like LPJ-GUESS. Moreover, the representation of SOM decomposition with first-order decay kinetics, as is included in LPJGUESS and other global models, has been criticised for being too simplistic (Schimel and Bennett, 2004). This commonly applied approach requires a somewhat artificial division of available $\mathrm{N}$ : first, soil microbes receive $\mathrm{N}$ for decomposition (immobilisation), afterwards the remainder is available for plant uptake. In other words, plants cannot adjust their competitive strength relative to microbes, resulting in possibly too low $\mathrm{N}$ availability for plant growth. A more complex approach, including an active compartment of litter-decomposing soil microorganisms that compete with plants for soil mineral $\mathrm{N}$, has been applied on the global scale (Esser et al., 2011) and might be a relevant approach to consider implementing in a future development of the model. Finally, for low-latitude ecosystems, including tropical forests, it has been argued that phosphorus $(\mathrm{P})$ constraints on biogeochemistry may be important to represent (Wang et al., 2010; Peñuelas et al., 2012).

For the 21st century, the single-factor responses simulated by LPJ-GUESS are similar to what has been found earlier using other DVMs (Sokolov et al., 2008; Fisher et al., 2010a; Zaehle et al., 2010; Goll et al., 2012). These models repre- sent $\mathrm{C}-\mathrm{N}$ interaction with varying degree of complexity and emphasise different processes (Table 1). TEM (Melillo et al., 1993; Felzer et al., 2004) is a process-based ecosystem model for monthly estimates of $\mathrm{C}$ and $\mathrm{N}$ fluxes and pool sizes based on referenced information on climate, soils, vegetation and water availability. FUN determines the $\mathrm{C}$ cost for acquiring $\mathrm{N}$ for productivity and is driven by nine parameters (NPP, biomass $\mathrm{C}$ and $\mathrm{N}$, etc) averaged over five DVM simulations (Fisher et al., 2010a). O-CN is developed from the DVM ORCHIDEE (Krinner et al., 2005) to include N effects on plant and soil processes (Zaehle and Friend, 2010). JSBACH is driven by NPP, leaf area index and climate as input to the model and simulates a background $\mathrm{N}$ limitation (Goll et al., 2012). Effects of some traceable differences in process representations in these models, compared to LPJ-GUESS, are discussed below.

LPJ-GUESS simulates lower $\mathrm{C}$ sequestration under a single-factor $\mathrm{CO}_{2}$ fertilisation scenario when $\mathrm{N}$ dynamics are enabled, which is consistent with ecological understanding (Vitousek and Howarth, 1991; Luo et al., 2004) and results from FACE experiments (Norby et al., 2010). The $61 \%$ reduction in $\mathrm{C}$ sequestration by the end of the 21 st century in the $\mathrm{C}-\mathrm{N}$ simulation with our model, compared to the $\mathrm{C}$ only version, is in agreement with results from other models, where an increased influence of $\mathrm{N}$ dynamics on $\mathrm{C}$ balance 
at higher latitudes, reducing the $\mathrm{CO}_{2}$ fertilisation effect, was likewise observed (Thornton et al., 2007; Jain et al., 2009; Zaehle et al., 2010).

A warming-induced increase in soil $\mathrm{N}$ mineralisation under climate change (Appendix Figs. A2 and A3) counteracts the relatively lower $\mathrm{C}$ uptake in mid/high latitudes found in the $\mathrm{CO}_{2}$ experiment. Similar to the historical simulations, accounting for $\mathrm{N}$ dynamics does not greatly influence future vegetation, litter and soil $\mathrm{C}$ dynamics in the lower latitudes; a similar decline under climate change occurred in both the $\mathrm{C}$-only and $\mathrm{C}-\mathrm{N}$ simulations. Globally, enhanced $\mathrm{N}$ mineralisation under warmer temperatures reduces cumulative $\mathrm{C}$ loss by c. $30 \%$ compared to the C-only version, which may be compared to a $16 \%$ loss reported by Zaehle et al. (2010) using the O-CN model. By contrast to effects of enhanced $\left[\mathrm{CO}_{2}\right]$ and globally warmer temperatures, effects of changing $\mathrm{N}$ deposition on $\mathrm{C}$ sequestration are negligible in LPJGUESS, partly because, during the 21 st century, most areas that experience $\mathrm{N}$ limitation under present-day climate will see rather small changes in $\mathrm{N}$ deposition fluxes according to the projections adopted for our study (Fig. A4). A limited effect of changing $\mathrm{N}$ deposition on global $\mathrm{C}$ sequestration has also been observed in other studies (Esser et al., 2011).

An interesting finding of our study is the presence of highly non-linear, synergistic, $\mathrm{N}$-mediated effects of multiple forcing factors on future global $\mathrm{C}$ balance. Whereas climate and $\left[\mathrm{CO}_{2}\right]$, applied independently, cause a decline in ecosystem $\mathrm{C}$ balance during the 21 st century, when these forcing factors are considered conjointly, the impacts on $\mathrm{C}$ balance are not only reduced but actually reversed, more $\mathrm{C}$ being sequestrated by the global biosphere when $\mathrm{N}$ cycle dynamics are included. This result stands in contrast to findings with a range of other DVMs in which increasing $\mathrm{N}$ limitations, particularly at mid/high latitudes, lead to a decline in biospheric C storage globally in a business-as-usual 21st century climate, $\left[\mathrm{CO}_{2}\right]$ and $\mathrm{N}$ deposition projection (Sokolov et al., 2008; Fisher et al., 2010a; Zaehle et al., 2010; Goll et al., 2012; see Table 1).

Shifting from strong N limitation of C uptake in the 20th century to high $\mathrm{C}$ sequestration during the 21 st century might seem puzzling from a mass balance perspective, but Smith et al. (2014) showed that the model response is within stoichiometric limits of how much $\mathrm{N}$ is needed to sustain $\mathrm{C}$ uptake (Hungate et al., 2003). This is also confirmed by the finding that the terrestrial ecosystem shifts from being a net $\mathrm{N}$ sink in the end of the 20th century to a net source by the end of the 21st century (Table A3), implying that many regions are becoming $\mathrm{N}$ saturated. Regionally, differences in $\mathrm{C}$ balance response between the C-only and $\mathrm{C}-\mathrm{N}$ simulations are mainly apparent in mid/high latitudes, where the $\mathrm{C}-\mathrm{N}$ version simulates a stronger increase in vegetation biomass, which is accompanied by an increase in litter $\mathrm{C}$, augmenting soil C pools (Table A1). These shifts for the $\mathrm{C}-\mathrm{N}$ version can also be seen in the increase of global $\mathrm{C}: \mathrm{N}$ ratios of both vegetation and soils (Table A3) as mid/high-latitude vegetation and soils have higher baseline $\mathrm{C}: \mathrm{N}$ ratios compared to the global averages. Simulated shifts in vegetation structure and PFT composition are fundamental to these adjustments in $\mathrm{C}$ and $\mathrm{N}$ balance.

In the $\mathrm{C}-\mathrm{N}$ simulation, woody vegetation abundance is initially lower, and the increase over the 21 st century in litter pool sizes with $\mathrm{N}$ dynamics is due to the slightly larger increase of woody vegetation $\mathrm{C}$ and lower initial litter pool sizes compared to the C-only version. Especially in the $\mathrm{mid} / \mathrm{high}$ latitudes the increase in woody vegetation has large impact on the $\mathrm{C}$ sequestrated. In response to the future projected changes in climate and $\mathrm{CO}_{2}$, woody vegetation in these regions becomes sufficiently dense for the process of self-thinning to be more prominent in the growth dynamics of the ecosystem, leading to notably enhanced litter input. This increased litter input can be observed in Fig. A1 as the sudden increase in litter $\mathrm{C}$ accumulated around year 2030, which more than compensates for warming-induced respiratory $\mathrm{C}$ loss through decomposition. Whether or not a similar ecosystem response would emerge also in different climate and $\mathrm{CO}_{2}$ scenarios has not yet been investigated - possibly the intersection of the C-sequestration curves of the two model version would happen at a later point in time. Moreover, the simulated ecosystem response is also sensitive to changes in its initial state. For instance, implementation of organic $\mathrm{N}$ uptake and/or a process-based representation of biological $\mathrm{N}$ fixation would lead in the $\mathrm{C}-\mathrm{N}$ version to shifts in its initial state, probably towards higher wood and litter C-pool sizes especially in mid/high-latitude areas, as more $\mathrm{N}$ is made available for plants, reducing $\mathrm{N}$ limitation. This would then affect the sudden increase in litter input seen with the present model at year 2030. In lower latitudes, $\mathrm{N}$ dynamics do not significantly limit $\mathrm{CO}_{2}$ fertilisation because of faster soil $\mathrm{N}$ mineralisation in a warmer climate (Fig. A5). As a result, $\mathrm{C}$ sequestration rates remain similar in the $\mathrm{C}-\mathrm{N}$ simulations compared to the C-only version for these areas. It should be borne in mind that, while low-latitude ecosystems may not be sensitive to $\mathrm{N}$ dynamics, $\mathrm{P}$ availability may impose limitations on C storage (Vitousek and Howarth, 1991; Vitousek et al., 2010; Wang et al., 2010; Goll et al., 2012). P limitations are not considered by our model. Overall, large uncertainties are associated with the results from DVMs, which should be kept in mind when comparing different models with respect to the net effects of introducing $\mathrm{N}$ limitation.

When comparing the different PFT distributions with the Haxeltine and Prentice (1996b) map of potential natural vegetation for the end of the 20th century, broad agreement of both model versions in geographic locations and ranges of major biome types is apparent (Smith et al., 2014). The $\mathrm{C}-\mathrm{N}$ version shows a better placement of the northern hemisphere boreal forest treeline compared to the $\mathrm{C}$-only version of the model, with the exception of eastern Siberia, where the $\mathrm{C}-\mathrm{N}$ version models a more limited extent of the Siberian Larix (larch) belt. The $\mathrm{C}-\mathrm{N}$ version also exhibits an improved placement of the southerly extent of the boreal forest in the 
dry regions of northern America and central Asia. For other regions, the $\mathrm{C}$-only and $\mathrm{C}-\mathrm{N}$ model versions simulate comparable PFT distributions.

$\mathrm{N}$ dynamics affect future vegetation composition most strongly in northern high-latitudes in our simulations. Severe $\mathrm{N}$ limitation associated with low $\mathrm{N}$ mineralisation rates constrains the ability of woody vegetation to compete for light and space with grasses (which may also be taken to represent other herbaceous vegetation and dwarf shrubs of tundra vegetation in these areas). As a result, poleward shifts in the taiga-tundra boundary, simulated in the C-only simulation, were not replicated in the $\mathrm{C}-\mathrm{N}$ simulation. This reduces the $\mathrm{C}$ sequestration in the stems of growing trees and results in smaller $\mathrm{C}$ sinks at high northern latitudes in the $\mathrm{C}-\mathrm{N}$ simulation compared to the C-only simulation (Figs. 3 and 4). This is most evident when comparing the future changes for locations a and d highlighted in Figs. 3 and 4. The bioclimatic limits enabling establishment of trees are reached simultaneously in both simulations, but due to continuing low soil temperatures, $\mathrm{N}$ mineralisation remains insufficient to sustain the establishment of new vegetation. In addition, the resident "tundra" ( $\mathrm{C}_{3}$ grass) vegetation has a competitive advantage with respect to the uptake of $\mathrm{N}$, further suppressing the establishment of trees. This emphasises again that future changes in $\mathrm{N}$ mineralisation may be the chief driving process for future ecosystem dynamics in high-latitude areas, overriding effects of atmospheric $\left[\mathrm{CO}_{2}\right]$ or climate. For locations c and h (Figs. 3 and 4), N limitations suppress woody vegetation in the historical part of the simulations, whereas in the future the limitation is removed. The level of suppression of trees under the present climate is too large for location $\mathrm{c}$ and might be explained by the failure to account for uptake of organic $\mathrm{N}$ by plants (see above). The explicit representation of competition among PFTs and its effects on vegetation structure and composition, mediated by population demographics, acts to retard the rate of vegetation response to changing environmental forcing, compared to models in which spatial changes in vegetation are strongly driven by bioclimatic thresholds for the presence or absence of PFTs (Pavlick et al., 2012). As future climate change is, under most emission scenarios, projected to occur at a higher pace than any historical climate change (Collins et al., 2013), shifts in the bioclimatic envelopes within which different vegetation types occur under present climate conditions may be expected to occur faster than observed before. However, studies of past climate change episodes generally point to considerable lags in migration rates of major vegetation types, due to dispersal, colonisation and demographic process that hinder and slow the establishment of new species on sites rendered climatically favourable by climate change (Malcolm et al., 2002; Gonzalez et al., 2010; Meier et al., 2012; Iverson and McKenzie, 2013). In our simulations, adjustments in $\mathrm{C}$ sequestration in the future projection are strongly tied to transient sinks of carbon in the stems of growing trees.
The vegetation-mediated lags inter alia in the vicinity of the taiga-tundra boundary play a key role in such dynamics.

Would not similar vegetation-dynamics mediated responses to $\mathrm{N}$ cycle dynamics be expected in conventional DVMs, lacking individual- and patch-based representations of vegetation structure and dynamics? In a comparison of LPJ-GUESS and the LPJ model, the latter incorporating identical representations of plant physiological and ecosystem biogeochemical processes, but a generalised, area-based representation of vegetation dynamics, Smith et al. (2001) showed that the explicit separation of individual and population growth in LPJ-GUESS resulted in different, and apparently more accurate, temporal evolution (succession) and equilibrium PFT composition of vegetation across the climate zones of Europe. Shortcomings in the performance of conventional DVMs with respect to reproducing structural features of vegetation have been highlighted in recent work. For example, Wolf et al. (2011) showed that models employing "big wood" schemes that combine environmental and structural dependencies of individual and population growth into a single, common parameterisation generally fail to reproduce allometric scaling relationships revealed by forest inventory data. Similarly, some conventional DVMs fail to account for the influence of disturbance on ecosystem structure at the landscape scale (Haverd et al., 2013). The explicit, individual- and patch-based representation of vegetation structural dynamics of our model may largely explain the contrasting predictions of $\mathrm{C}-\mathrm{N}$ dynamics under climate warming and $\mathrm{CO}_{2}$ enrichment, compared with previous findings based on other models.

\section{Concluding remarks}

The results shown in this study add a new perspective to the previous inconclusive evidence on how strongly - and in what direction - terrestrial $\mathrm{N}$ cycle dynamics will affect future $\mathrm{C}$ sequestration by the terrestrial biosphere. Results from our individual-based DVM exhibit slightly increased $\mathrm{C}$ sequestration under a business-as-usual future climate scenario when $\mathrm{N}$ cycle dynamics are accounted for, contrasting with results previously reported from other models, which universally point to a decline in ecosystem $\mathrm{C}$ stocks under climate projections for the coming century (Sokolov et al., 2008; Fisher et al., 2010a; Zaehle et al., 2010; Goll et al., 2012). Transient sinks for $C$ in the stems of trees colonising new areas, or undergoing demographic adjustment within existing forest stands, account for such dynamics in our model, and likely explain why the results deviate from other studies with models lacking explicit representation of population dynamics, neighbourhood-level resource competition, and associated lags in the response of vegetation structure and distribution to climate change.

LPJ-GUESS, like most current DVMs, lacks a dynamic representation of organic $\mathrm{N}$ uptake, and it is possible that 
$\mathrm{N}$ limitations, and the subsequent release from limitation through climate warming, in mid/high latitudes might therefore be overestimated.
Our contrasting - but plausible - results of future $\mathrm{C}-\mathrm{N}$ coupling add to the still considerable uncertainty as to the likely fate of present-day biospheric carbon sinks, and the influence of $\mathrm{C}-\mathrm{N}$ interactions on these, in a future warmer and high- $\mathrm{CO}_{2}$ world. As ecosystem and Earth system models are developed to account for $\mathrm{N}$ cycle dynamics there is still a need for carefully designed empirical studies of $\mathrm{N}$ cycle impacts on $\mathrm{C}$ biogeochemistry in a range of ecosystem types and in response to multiple environmental forcing factors, emulating global change, to adequately constrain the models and reduce model uncertainties. 


\section{Appendix A}

Table A1. Modelled C sequestration between 1850 to 2100 [PgC] for climate change (CLIM), atmospheric $\left[\mathrm{CO}_{2}\right]\left(\mathrm{CO}_{2}\right), \mathrm{N}$ deposition (NDEP) alone, and all together (ALL).

\begin{tabular}{lrrrrrr}
\hline & & Veg C & Litter C & Soil C & Total & $\%$ diff \\
\hline \multirow{2}{*}{ ALL } & C-only & 373 & -23 & -33 & 317 & \\
& C-N & 372 & 28 & -28 & 372 & 17 \\
CLIM & C-only & -200 & -164 & -101 & -465 & \\
& C-N & -120 & -108 & -92 & -320 & -31 \\
CO2 & C-only & 633 & 193 & 97 & 924 & \\
& C-N & 239 & 65 & 57 & 361 & -61 \\
NDEP & C-only & - & - & - & - & \\
& C-N & 58 & -6 & 3 & 55 & \\
& & & & & &
\end{tabular}

Table A2. Initial conditions for the C-only and C-N model versions, after spin-up.

\begin{tabular}{lrrrrrrrr}
\hline Variable $^{1}$ & $\mathrm{NPP}$ & $R_{\mathrm{h}}$ & $\mathrm{BB}$ & $\mathrm{NCB}$ & $\mathrm{Veg} \mathrm{C}$ & Litter C & Soil C & Total C \\
\hline Unit & ${\mathrm{PgC} \mathrm{yr}^{-1}}^{-1}$ & $\mathrm{PgC} \mathrm{yr}^{-1}$ & $\mathrm{PgC} \mathrm{yr}^{-1}$ & $\mathrm{PgC} \mathrm{yr}^{-1}$ & $\mathrm{PgC}$ & $\mathrm{PgC}$ & $\mathrm{PgC}$ & $\mathrm{PgC}$ \\
\hline C-only & 56.0 & 49.4 & 6.4 & -0.2 & 697 & 435 & 1245 & 2377 \\
C-N & 53.1 & 48.5 & 4.5 & -0.1 & 519 & 297 & 1197 & 2014 \\
\hline
\end{tabular}

${ }^{1} \mathrm{NPP}=$ net primary production; $R_{\mathrm{h}}=$ heterotrophic respiration; $\mathrm{BB}=$ biomass burning by wildfires; $\mathrm{NCB}=$ net ecosystem $\mathrm{C}$ balance $=R_{\mathrm{h}}+\mathrm{BB}-\mathrm{NPP} ;$ Veg $\mathrm{C}=$ vegetation $\mathrm{C}$.

Table A3. Changes in $\mathrm{N}$ stocks and fluxes for the $\mathrm{C}-\mathrm{N}$ version of the model under all scenarios.

\begin{tabular}{|c|c|c|c|c|c|}
\hline Variable & Units & 1961 to 1990 & 2071 to 2100 & Units & 1976 to 2086 \\
\hline Vegetation $\mathrm{C}: \mathrm{N}$ & $\operatorname{kgC}(\mathrm{kgN})^{-1}$ & 142.9 & 159.9 & $\%^{1}$ & 11.9 \\
\hline Soil + litter C:N & $\operatorname{kgC}(\operatorname{kgN})^{-1}$ & 12.6 & 12.8 & $\%^{1}$ & 1.0 \\
\hline Vegetation $\mathrm{N}$ & $\mathrm{PgN}$ & 3.9 & 5.3 & $\mathrm{PgN}^{2}$ & 1.4 \\
\hline Soil + litter N & $\mathrm{PgN}$ & 117.0 & 116.8 & $\mathrm{PgN}^{2}$ & -0.1 \\
\hline $\mathrm{N}$ storage change & & & & $\mathrm{PgN}^{2}$ & 1.3 \\
\hline $\mathrm{N}$ deposition & $\mathrm{TgN}_{\mathrm{yr}}{ }^{-1}$ & -52.1 & -78.2 & $\mathrm{PgN}^{3}$ & -7.7 \\
\hline $\mathrm{N}$ fixation & $\mathrm{TgN} \mathrm{yr}^{-1}$ & -28.6 & -26.6 & $\mathrm{PgN}^{3}$ & -3.0 \\
\hline $\mathrm{N}$ leaching & $\mathrm{TgN}_{\mathrm{yr}}{ }^{-1}$ & 17.8 & 26.5 & $\mathrm{PgN}^{3}$ & 6.9 \\
\hline $\mathrm{N}$ emission & $\mathrm{TgN} \mathrm{yr}^{-1}$ & 47.4 & 79.2 & $\mathrm{PgN}^{3}$ & 2.5 \\
\hline Net flux & $\mathrm{TgN}_{\mathrm{yr}}{ }^{-1}$ & -15.4 & 0.8 & $\mathrm{PgN}^{3}$ & -1.3 \\
\hline
\end{tabular}

${ }^{1}$ Percentage change in C: N ratios between periods 1961 to 1990 and 2071 to $2100 .{ }^{2}$ Change in N storage between periods 1961 to 1990 and 2071 to $2100 .{ }^{3}$ Cumulative N fluxes between periods 1961 to 1990 and 2071 to 2100 . 

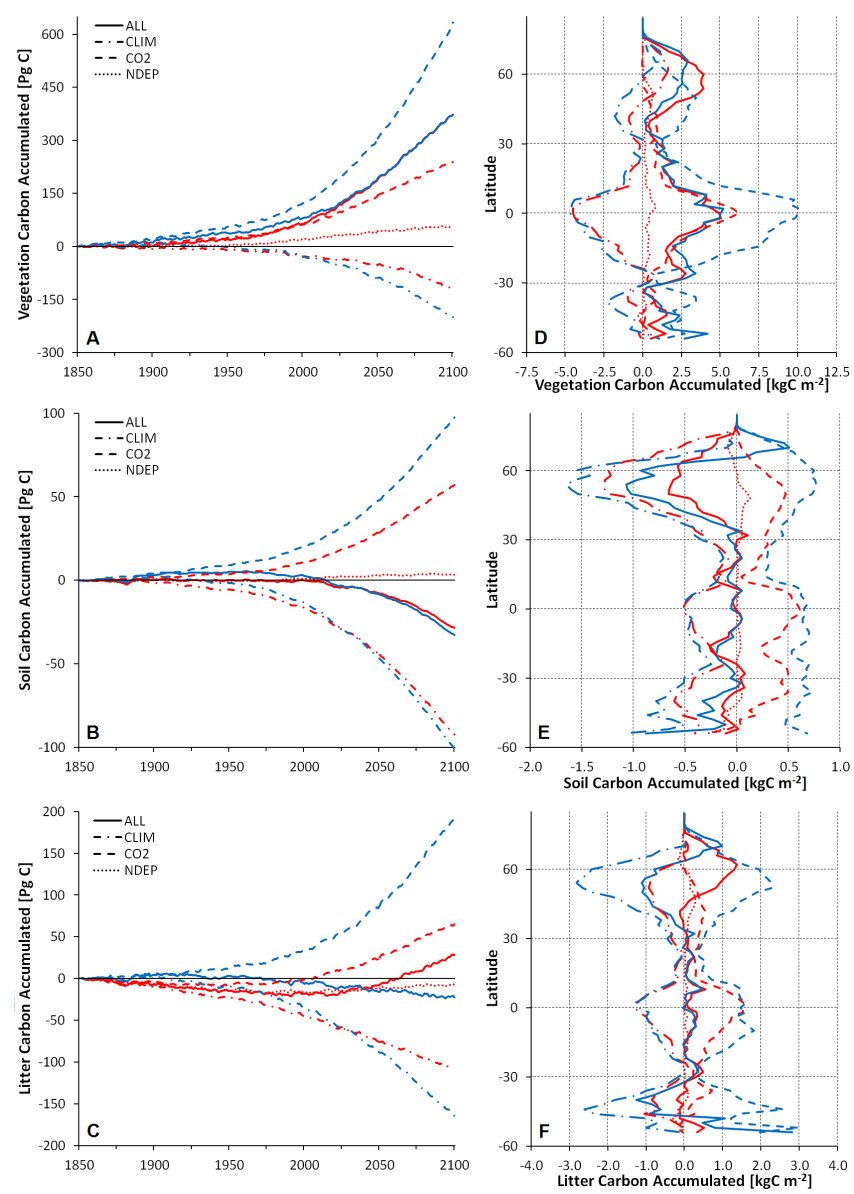

Figure A1. Cumulative vegetation (a), soil (b), and litter (c) $\mathrm{C}$ sequestrated between 1850 and 2100 simulated with historical and future change in climate (CLIM), atmospheric $\left[\mathrm{CO}_{2}\right](\mathrm{CO} 2), \mathrm{N}$ deposition (NDEP) alone, and all together (ALL). (d-f) show accumulated $\mathrm{C}$ by latitude over the period 2000-2100. Blue lines C-only version and red lines are $\mathrm{C}-\mathrm{N}$ version.

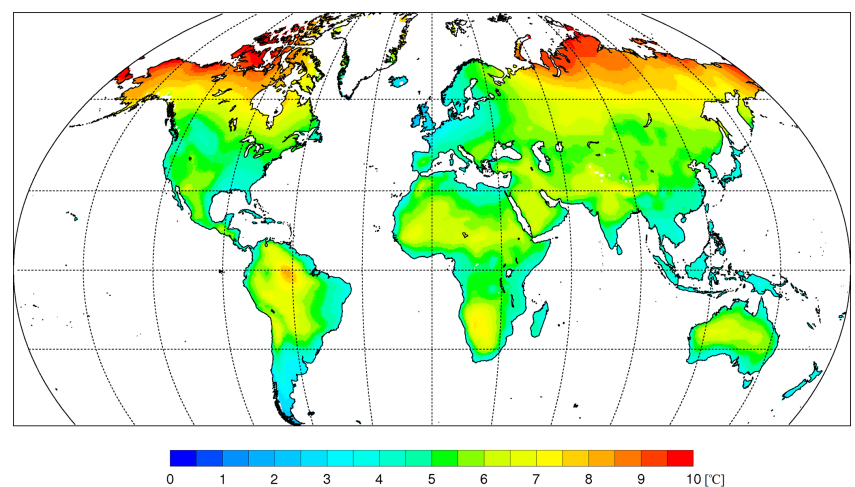

Figure A2. Temperature change during the 21 st century simulated with MPI-ESM-LR under RCP 8.5. Shown is the difference between average values computed for 1990-2000 and 2090-2100. Data were bias-corrected following Ahlström et al. (2013).

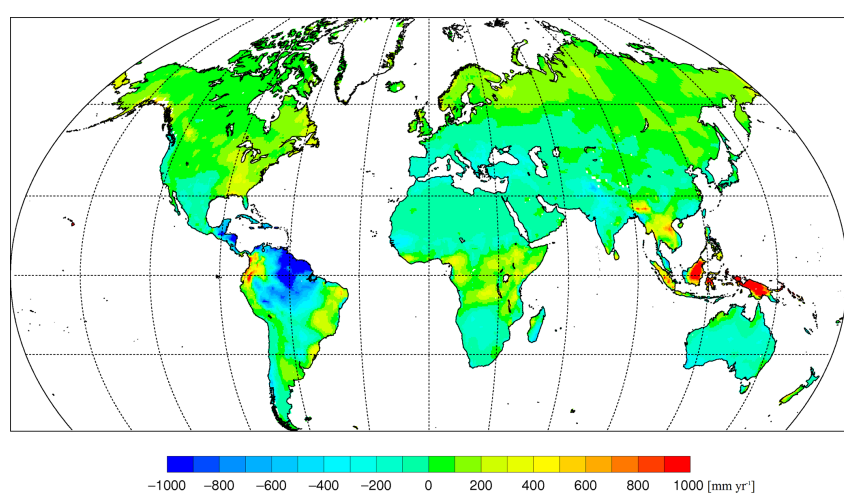

Figure A3. Precipitation change during the 21st century simulated with MPI-ESM-LR under RCP 8.5. Shown is the difference between average values computed for 1990-2000 and 2090-2100. Data were bias-corrected following Ahlström et al. (2013).

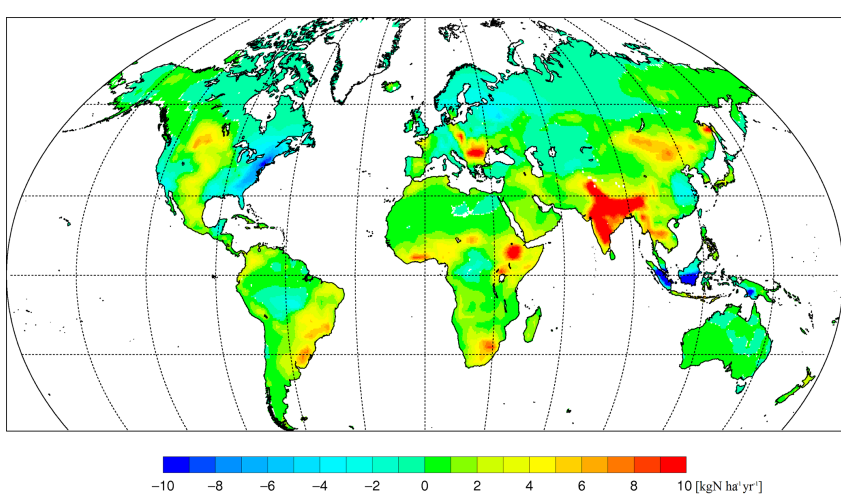

Figure A4. Anthropogenic N deposition change during the 21st century, simulated with the CAM model (Gent et al., 2010) under RCP 8.5. Shown is the difference between average values computed for 1990-2000 and 2090-2100.

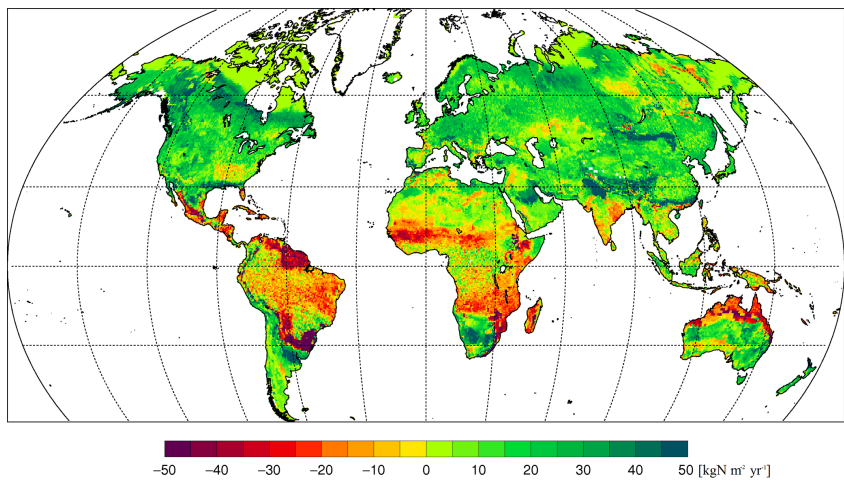

Figure A5. Change in net N-mineralisation during the 21 st century, under the ALL scenario. Shown is the difference between average values computed for 1990-2000 and 2090-2100. 


\section{The Supplement related to this article is available online at doi:10.5194/bg-11-6131-2014-supplement.}

Acknowledgements. This study is a contribution to the Linnaeus Centre of Excellence LUCCI, the Strategic Research Areas BECC and MERGE, Formas Strong Research Environment "Land use today and tomorrow", FP7 project EMBRACE (grant no. 282672). T. Hickler acknowledges support from the research funding programme "LOEWE-Landesoffensive zur Entwicklung Wissenschaftlich-ökonomischer Exzellenz” of Hesse's Ministry of Higher Education.

Edited by: A. Rammig

\section{References}

Ahlström, A., Schurgers, G., Arneth, A., and Smith, B.: Robustness and uncertainty in terrestrial ecosystem carbon response to CMIP5 climate change projections, Environ. Res. Lett., 7, 4, doi:10.1088/1748-9326/7/4/044008, 2012.

Arneth, A., Schurgers, G., Hickler, T., and Miller, P. A.: Effects of species composition, land surface cover, $\mathrm{CO}_{2}$ concentration and climate on isoprene emissions from European forests, Plant Biol., 10, 150-162. doi:110.1055/s-2007-965247, 2008.

Arneth, A., Harrison, S.P., Zaehle, S., Tsigaridis, K., Menon, S., Bartlein, P. J., Feichter, J., Korhola, A., Kulmala, M., O’Donnell, D., Schurgers, G., Sorvari, S., and Vesala, T.: Terrestrial biogeochemical feedbacks in the climate system, Nat.Geosci., 3, 525-532, 2010a.

Arneth, A., Lehsten, V., Thonicke, K., and Spessa, A.: Climate-fire interactions and savanna ecosystems: a dynamic vegetation modelling study for the African continent, in: Ecosystem Function in Savannas: Measurement and Modeling at Landscape to Global Scales, edited by: Hannan, N. and Hill, M., Taylor and Francis, 463-478, 2010b.

Arora, V. K., Boer, G. J., Friedlingstein, P., Eby, M., Jones, C. D., Christian, J. R., Bonan, G., Bopp, L., Brovkin, V., Cadule, P., Hajima, T., Ilyina, T., Lindsay, K., Tjiputra, J. F., and Wu, T.: Carbon-concentration and carbon-climate feedbacks in CMIP5 Earth system models, J. Clim., 26, 5289-5314, 2013.

Beier, C.: Climate change and ecosystem function - full-scale manipulations of $\mathrm{CO}_{2}$ and temperature, New Phytol., 162, 243-245, 2004.

Bugmann, H.: A review of forest gap models, Clim. Change, 51, 259-305, 2001.

Canadell, J. G., Le Quere, C., Raupach, M. R., Field, C. B., Buitenhuis, E. T., Ciais, P., Conway, T. J., Gillett, N. P., Houghton, R. A., and Marland, G.: Contributions to accelerating atmospheric $\mathrm{CO}(2)$ growth from economic activity, carbon intensity, and efficiency of natural sinks, Proc. Natl. Acad. Sci. USA, 104, 18866-18870, 2007.

Cleveland, C. C., Townsend, A. R., Schimel, D. S., Fisher, H., Howarth, R. W., Hedin, L. O., Perakis, S. S., Latty, E. F., Von Fischer, J. C., Elseroad, A., and Wasson, M. F.: Global patterns of terrestrial biological nitrogen $(\mathrm{N}-2)$ fixation in natural ecosystems, Global Biogeochem. Cy., 13, 623-645, 1999 ..
Collins, M., Knutti, R., Arblaster, J., Dufresne, J.-L., Fichefet, T., Friedlingstein, P., Gao, X., Gutowski, W. J., Johns, T., Krinner, G., Shongwe, M., Tebaldi, C., Weaver, A. J., and Wehner, M.: Long-term climate change: Projections, commitments and irreversibility, in: Climate Change 2013: The Physical Science Basis, Contribution of Working Group I to the Fifth Assessment Report of the Intergovernmental Panel on Climate Change, edited by: Stocker, T. F., Qin, D., Plattner, G.-K., Tignor, M., Allen, S. K., Doschung, J., Nauels, A., Xia, Y., Bex, V., and Midgley, P. M., Cambridge University Press, 1029-1136, 2013.

Comins, H. N. and McMurtrie, R. E.: Long-Term Response of Nutrient-Limited Forests to $\mathrm{CO}_{2}$ Enrichment - Equilibrium Behavior of Plant-Soil Models, Ecol. Appl., 3, 666-681, 1993.

De Kauwe, M. G., Medlyn, B. E., Zaehle, S., Walker, A. P., Dietze, M. C., Hickler, T., Jain, A. K., Luo, Y., Parton, W. J., Prentice, I. C., Smith, B., Thornton, P. E., Wang, S., Wang, Y.-P., Wårlind, D., Weng, E., Crous, K. Y., Ellsworth, D. S., Hanson, P. J., Seok Kim, H., Warren, J. M., Oren, R., and Norby, R. J.: Forest water use and water use efficiency at elevated $\mathrm{CO}_{2}$ : a model-data intercomparison at two contrasting temperate forest FACE sites, Glob. Change Biol., 19, 1759-1779, 2013.

Esser G., Kattge J., and Sakalli A.: Feedback of carbon and nitrogen cycles enhances carbon sequestration in the terrestrial biosphere, Glob. Change Biol., 17, 819-842, 2011.

Felzer, B., Kicklighter, D. W., Melillo, J. M., Wang, C., Zhuang, Q., and Prinn, R.: Effects of ozone on net primary production and carbon sequestration in the conterminous United States using a biogeochemistry model, Tellus B, 56, 230-248, 2004.

Finzi, A. C., Norby, R. J., Calfapietra, C., Gallet-Budynek, A., Gielen, B., Holmes, W. E., Hoosbeek, M. R., Iversen, C. M., Jackson, R. B., Kubiske, M. E., Ledford, J., Liberloo, M., Oren, R., Polle, A., Pritchard, S., Zak, D. R., Schlesinger, W. H., and Ceulemans, R.: Increases in nitrogen uptake rather than nitrogen-use efficiency support higher rates of temperate forest productivity under elevated $\mathrm{CO}_{2}$, P. Natl. Acad. Sci. USA, 104, 14014-14019, 2007.

Fisher, J. B., Sitch, S., Malhi, Y., Fisher, R. A., Huntingford, C., and Tan, S. Y.: Carbon cost of plant nitrogen acquisition: A mechanistic, globally applicable model of plant nitrogen uptake, retranslocation, and fixation, Global Biogeochem. Cy., 24, GB1014, doi:10.1029/2009GB003621, 2010a.

Fisher, R., McDowell, N., Purves, D., Moorcroft, P., Sitch, S., Cox, P., Huntingford, C., Meir, P., and Ian Woodward, F.: Assessing uncertainties in a second-generation dynamic vegetation model caused by ecological scale limitations, New Phytol. 187, 666-681, 2010b.

Fleischer, K., Wårlind, D., van der Molen, M., Rebel, K., Erisman, J.W., Arneth, A., Wassen, M., Smith, B., Gough, C., Margolis, H., Cescatti, A., Montagnani, L., Arain, A., and Dolman, H.: Modelling carbon-nitrogen cycle dynamics and the effect of nitrogen deposition on forest carbon sequestration, Biogeosciences, submitted, 2013.

Friedlingstein, P., Cox, P., Betts, R., Bopp, L., Von Bloh, W., Brovkin, V., Cadule, P., Doney, S., Eby, M., Fung, I., Bala, G., John, J., Jones, C., Joos, F., Kato, T., Kawamiya, M., Knorr, W., Lindsay, K., Matthews, H.D., Raddatz, T., Rayner, P., Reick, C., Roeckner, E., Schnitzler, K.G., Schnur, R., Strassmann, K., Weaver, A.J., Yoshikawa, C., and Zeng, N.: Climate-carbon 
cycle feedback analysis: Results from the (CMIP)-M-4 model intercomparison, J. Climate, 19, 3337-3353, 2006.

Friend, A. D., Stevens, A. K., Knox, R. G., and Cannell, M. G. R.: A process-based, terrestrial biosphere model of ecosystem dynamics (Hybrid v3.0), Ecol. Modell., 95, 249-287, 1997.

Galloway, J. N., Townsend, A. R., Erisman, J. W., Bekunda, M., Cai, Z., Freney, J. R., Martinelli, L. A., Seitzinger, S. P., and Sutton, M. A.: Transformation of the nitrogen cycle: Recent trends, questions, and potential solutions, Science, 320, 889-892, 2008.

Gent, P. R., Yeager, S. G., Neale, R. B., Levis, S., and Bailey, D. A.: Improvements in a half degree atmosphere/land version of the CCSM, Clim. Dynam., 34, 819-833, 2010.

Giorgetta, M. A., Jungclaus, J., Reick, C. H., Legutke, S., Bader, J., Böttinger, M., Brovkin, V., Crueger, T., Esch, M., Fieg, K., Glushak, K., Gayler, V., Haak, H., Hollweg, H.-D., Ilyina, T., Kinne, S., Kornblueh, L., Matei, D., Mauritsen, T., Mikolajewicz, U., Mueller, W., Notz, D., Pithan, F., Raddatz, T., Rast, S., Redler, R., Roeckner, E., Schmidt, H., Schnur, R., Segschneider, J., Six, K.D., Stockhause, M., Timmreck, C., Wegner, J., Widmann, H., Wieners, K.-H., Claussen, M., Marotzke, J., and Stevens, B.: Climate and carbon cycle changes from 1850 to 2100 in MPI-ESM simulations for the coupled model intercomparison project phase 5, J. Adv. Model. Earth Syst., 5, 572-597, 2013.

Goll, D. S., Brovkin, V., Parida, B. R., Reick, C. H., Kattge, J., Reich, P. B., van Bodegom, P. M., and Niinemets, Ü.: Nutrient limitation reduces land carbon uptake in simulations with a model of combined carbon, nitrogen and phosphorus cycling, Biogeosciences, 9, 3547-3569, doi:10.5194/bg-9-3547-2012, 2012.

Gonzalez, P., Neilson, R. P., Lenihan, J. M., and Drapek, R. J.: Global patterns in the vulnerability of ecosystems to vegetation shifts due to climate change, Glob. Ecol. Biogeogr., 19, 755-768, 2010.

Haverd, V., Smith, B., Cook, G. D., Briggs, P. R., Nieradzik, L., Roxburgh, S. R., Liedloff, A., Meyer, C. P., and Canadell, J. G.: A stand-alone tree demography and landscape structure module for Earth system models, Geophys. Res. Lett., 40, 5234-5239, 2013.

Haxeltine, A. and Prentice, I. C.: A general model for the lightuse efficiency of primary production, Funct. Ecol., 10, 551-561, 1996a.

Haxeltine, A. and Prentice, I. C.: BIOME3: An equilibrium terrestrial biosphere model based on ecophysiological constraints, resource availability, and competition among plant functional types, Global Biogeochem. Cy., 10, 693-709, 1996 b.

Heimann, M. and Reichstein, M.: Terrestrial ecosystem carbon dynamics and climate feedbacks, Nature, 451, 289-292, 2008.

Hély, C., Bremond, L., Alleaume, S., Smith, B., Sykes, M. T., and Guiot, J.: Sensitivity of African biomes to changes in the precipitation regime, Global Ecol. Biogeogr., 15, 258-270, 2006.

Hickler, T., Smith, B., Sykes, M. T., Davis, M. B., Sugita, S., and Walker, K.: Using a generalized vegetation model to simulate vegetation dynamics in the western Great Lakes region, USA, under alternative disturbance regimes, Ecology, 85, 519-530 2004.

Hickler, T., Vohland, K., Feehan, J., Miller, P. A., Smith, B., Costa, L., Giesecke, T., Fronzek, S., Carter, T. R., Cramer, W., Kühn, I., and Sykes, M. T.: Projecting the future distribution of European potential natural vegetation zones with a generalized, tree species-based dynamic vegetation model, Global Ecol. Biogeogr., 21, 50-63, 2012.

Hungate, B. A., Dukes, J. S., Shaw, M. R., Luo, Y. Q., and Field, C. B.: Nitrogen and climate change, Science, 302, 1512-1513, 2003.

Iverson, L. R. and McKenzie, D.: Tree-species range shifts in a changing climate: detecting, modeling, assisting, Lands. Ecol., 28, 879-889, 2013.

Jain, A., Yang, X. J., Kheshgi, H., McGuire, A. D., Post, W., and Kicklighter, D.: Nitrogen attenuation of terrestrial carbon cycle response to global environmental factors, Global Biogeochem. Cy., 23, GB4028, doi:10.1029/2009GB003519, 2009.

Kirschbaum, M. U. F. and Paul, K. I.: Modelling C and N dynamics in forest soils with a modified version of the CENTURY model, Soil Biol. Biochem., 34, 341-354, 2002.

Krinner, G., Viovy, N., de Noblet-Ducoudrè, N., Ogeé, J., Polcher, J., Friedlingstein, P., Ciais, P., Sitch, S., and Prentice, I. C.: A dynamic global vegetation model for studies of the coupled atmosphere-biospheresystem, Global Biogeochem. Cy., 19, GB1015, doi:10.1029/2003GB002199, 2005.

Lamarque, J.-F., Bond, T. C., Eyring, V., Granier, C., Heil, A., Klimont, Z., Lee, D., Liousse, C., Mieville, A., Owen, B., Schultz, M. G., Shindell, D., Smith, S. J., Stehfest, E., Van Aardenne, J., Cooper, O. R., Kainuma, M., Mahowald, N., McConnell, J. R., Naik, V., Riahi, K., and van Vuuren, D. P.: Historical (1850-2000) gridded anthropogenic and biomass burning emissions of reactive gases and aerosols: methodology and application, Atmos. Chem. Phys., 10, 7017-7039, doi:10.5194/acp10-7017-2010, 2010.

Lamarque, J.-F., Kyle, G. P., Meinshausen, M., Riahi, K., Smith, S. J., van Vuuren, D. P., Conley, A. J., and Vitt, F.: Global and regional evolution of short-lived radiatively-active gases and aerosols in the Representative Concentration Pathways, Clim. Change, 109, 191-212, 2011.

Leuzinger, S., Luo, Y., Beier, C., Dieleman, W., Vicca, S., and Koerner, C.: Do global change experiments overestimate impacts on terrestrial ecosystems?, Trends Ecol. Evolut., 26, 236-241, 2011.

Lindeskog, M., Arneth, A., Bondeau, A., Waha, K., Seaquist, J., Olin, S., and Smith, B.: Implications of accounting for land use in simulations of ecosystem carbon cycling in Africa, Earth Syst. Dynam., 4, 385-407, doi:10.5194/esd-4-385-2013, 2013.

Luo, Y., Su, B., Currie, W. S., Dukes, J. S., Finzi, A., Hartwig, U., Hungate, B., McMurtrie, R. E., Oren, R., Parton, W. J., Pataki, D. E., Shaw, M. R., Zak, D. R., and Field, C. B.: Progressive nitrogen limitation of ecosystem responses to rising atmospheric carbon dioxide, BioScience, 54, 731-740, 2004.

McCarthy H. R., Oren, R., Johnsen, K. H., Gallet-Budynek, A., Pritchard, S. G., Cook, C. W., LaDeau, S. L., Jackson, R. B., and Finzi, A. C.: Re-assessment of plant carbon dynamics at the Duke free-air $\mathrm{CO}_{2}$ enrichment site: Interactions of atmospheric $\left[\mathrm{CO}_{2}\right]$ with nitrogen and water availability over stand development, New Phytol., 185, 514-528, 2010.

Malcolm, J. R., Markham, A., Neilson, R. P., and Garaci, M.: Estimated migration rates under scenarios of global climate change, J. Biogeogr., 29, 835-849, 2002.

Meier, E. S., Lischke, H., Schmatz, D. R., and Zimmermann, N. E.: Climate, competition and connectivity affect future migration and ranges of European trees, Glob. Ecol. Biogeogr., 21, 164-178, 2012. 
Mellilo, J. M., McGuire, A. D., Kicklighter, D. W., Moore III, B., Vorosmarty, C. J., and Schloss, A. L.: Global climate change and terrestrial net primary production, Nature, 363, 234-240, 1993.

Melillo, J. M., Butler, S., Johnson, J., Mohan, J., Steudler, P., Lux, H., Burrows, E., Bowles, F., Smith, R., Scott, L., Vario, C., Hill, T., Burton, A., Zhou, Y.-M., and Tang, J.: Soil warming, carbon-nitrogen interactions, and forest carbon budgets, Proc. Natl. Acad. Sci. USA, 108, 9508-9512, 2011.

Mitchell, T. D. and Jones, P. D.: An improved method of constructing a database of monthly climate observations and associated high-resolution grids, Internat. J. Climatol., 25, 693-712, 2005.

Moorcroft, P. R., Hurtt, G. C., and Pacala, S. W.: A method for scaling vegetation dynamics: The ecosystem demography model (ED), Ecol. Monogr., 71, 557-585, 2001.

Norby, R. J., Warren, J. M., Iversen, C. M., Medlyn, B. E., and McMurtrie, R. E.: $\mathrm{CO}(2)$ enhancement of forest productivity constrained by limited nitrogen availability, Proc. Natl. Acad. Sci. USA, 107, 19368-19373, 2010.

Näsholm, T., Ekblad, A., Nordin, A., Giesler, R., Hogberg, M., and Hogberg, P.: Boreal forest plants take up organic nitrogen, Nature, 392, 914-916, 1998.

Näsholm, T., Kielland, K., and Ganeteg, U.: Uptake of organic nitrogen by plants, New Phytol., 182, 31-48, 2009.

Parton, W. J., Hanson, P. J., Swanston, C., Torn, M., Trumbore, S. E., Riley, W., and Kelly, R.: ForCent model development and testing using the Enriched Background Isotope Study experiment, J. Geophys. Res.-Biogeosci., 115, G4, doi:10.1029/2009JG001193, 2010.

Parton, W. J., Scurlock, J. M. O., Ojima, D. S., Gilmanov, T. G., Scholes, R. J., Schimel, D. S., Kirchner, T., Menaut, J. C., Seastedt, T., Moya, E. G., Kamnalrut, A., and Kinyamario, J. I.: Observations and Modeling of Biomass and Soil Organic-Matter Dynamics for the Grassland Biome Worldwide, Global Biogeochem. Cy., 7, 785-809, 1993.

Pavlick, R., Drewry, D. T., Bohn, K., Reu, B., and Kleidon, A.: The Jena Diversity-Dynamic Global Vegetation Model (JeDiDGVM): a diverse approach to representing terrestrial biogeography and biogeochemistry based on plant functional trade-offs, Biogeosciences, 10, 4137-4177, doi:10.5194/bg-10-4137-2013, 2012.

Peñuelas, J., Sardans, J., Rivas-Ubach, A., and Janssens, I. A.: The human-induced imbalance between $\mathrm{C}, \mathrm{N}$ and $\mathrm{P}$ in Earth's life system, Glob. Change Biol., 18, 3-6, 2012.

Purves, D. and Pacala, S.: Predictive models of forest dynamics, Science, 320, 1452-1453, 2008.

Scheiter, S. and Higgins, S.: Impacts of climate change on the vegetation of Africa: an adaptive dynamic vegetation modelling approach, Glob. Change Biol., 15, 2224-2246, 2009.

Raupach, M. R.: Pinning down the land carbon sink, Nat. Clim. Change, 1, 148-149, 2011.

Schimel, J. P., and Bennett, J.: Nitrogen mineralization: challenges of a changing paradigm, Ecology, 85, 591-602, 2004.

Schulze, E.-D.: Biological control of the terrestrial carbon sink, Biogeosciences, 3, 147-166, doi:10.5194/bg-3-147-2006, 2006.

Sitch, S., Huntingford, C., Gedney, N., Levy, P. E., Lomas, M., Piao, S. L., Betts, R., Ciais, P., Cox, P., Friedlingstein, P., Jones, C. D., Prentice, I. C., and Woodward, F. I.: Evaluation of the terrestrial carbon cycle, future plant geography and climate-carbon cycle feedbacks using five Dynamic Global Vegetation Models (DGVMs), Glob. Change Biol., 4, 2015-2039, 2008.

Sitch, S., Smith, B., Prentice, I. C., Arneth, A., Bondeau, A., Cramer, W., Kaplan, J. O., Levis, S., Lucht, W., Sykes, M. T., Thonicke, K., and Venevsky, S.: Evaluation of ecosystem dynamics, plant geography and terrestrial carbon cycling in the LPJ dynamic global vegetation model, Glob. Change Biol., 9, 161-185, 2003.

Smith, B., Prentice, I. C., and Sykes, M. T.: Representation of vegetation dynamics in the modelling of terrestrial ecosystems: comparing two contrasting approaches within European climate space, Glob. Ecol. Biogeogr., 10, 621-637, 2001.

Smith, B., Wårlind, D., Arneth, A., Hickler, T., Leadley, P., Siltberg, J., and Zaehle, S.: Implications of incorporating N cycling and $\mathrm{N}$ limitations on primary production in an individual-based dynamic vegetation model, Biogeosciences, 11, 2027-2054, doi:10.5194/bg-11-2027-2014, 2014.

Sokolov, A. P., Kicklighter, D. W., Melillo, J. M., Felzer, B. S., Schlosser, C. A., and Cronin, T. W.: Consequences of considering carbon-nitrogen interactions on the feedbacks between climate and the terrestrial carbon cycle, J. Climate, 21, 3776-3796, 2008.

Stocker, B. D., Roth, R., Joos, F., Spahni, R., Steinacher, M., Zaehle, S., Bouwman, L., Xu, R., and Prentice, I. C.: Multiple greenhouse-gas feedbacks from the land biosphere under future climate change scenarios, Nature Clim. Change, 3, 666-672, 2013.

Tang, G., Beckage, B., and Smith, B.: The potential transient dynamics of forests in New England under historical and projected future climate change, Clim. Change, 114, 357-377, 2012.

Thornton, P. E., Lamarque J. F., Rosenbloom N. A., and Mahowald, N. M.: Influence of carbon-nitrogen cycle coupling on land model response to $\mathrm{CO}_{2}$ fertilization and climate variability, Global Biogeochem. Cy., 21, GB4018, doi:10.1029/2006GB002868, 2007.

Thornton, P. E., Doney, S. C., Lindsay, K., Moore, J. K., Mahowald, N., Randerson, J. T., Fung, I., Lamarque, J. F., Feddema, J. J., and Lee, Y. H.: Carbon-nitrogen interactions regulate climate-carbon cycle feedbacks: results from an atmosphere-ocean general circulation model, Biogeosciences, 6, 2099-2120, 2009,

http://www.biogeosciences.net/6/2099/2009/.

Wang, Y. P., Law, R. M., and Pak, B.: A global model of carbon, nitrogen and phosphorus cycles for the terrestrial biosphere, Biogeosciences, 7, 2261-2282, doi:10.5194/bg-7-2261-2010, 2010.

White, M. A., Thornton, P. E., Running, S., and Nemani, R.: Parameterization and Sensitivity Analysis of the BIOME-BGC Terrestrial Ecosystem Model: Net Primary Production Controls, Earth Int., 4, 1-55, 2000.

Vitousek, P. M. and Howarth, R. W.: Nitrogen limitation on land and in the sea: How can it occur?, Biogeochemistry, 13, 87-115, 1991.

Vitousek, P. M., Porder, S., Houlton, B. Z., and Chadwick, O. A.: Terrestrial phosphorus limitation: mechanisms, implications, and nitrogen-phosphorus interactions, Ecol. Appl., 20, 5-15, 2010.

Wolf, A., Ciais, P., Bellassen, V., Delbart, N., Field, C. B., and Berry, J. A.: Forest biomass allometry in global land surface models. Global Biogeochem. Cy., 25, GB3015, doi:10.1029/2010GB003917, 2011. 
Wright, I. J. and Westoby, M.: Nutrient concentration, resorption and lifespan: leaf traits of Australian sclerophyll species, Funct. Ecol., 17, 10-19, 2003.

Zaehle, S. and Friend, A. D.: Carbon and nitrogen cycle dynamics in the O-CN land surface model: 1. Model description, site-scale evaluation, and sensitivity to parameter estimates, Global Biogeochem. Cy., 24, GB1005, doi:10.1029/2009GL041345, 2010.
Zaehle, S., Friedlingstein, P., and Friend, A. D.: Terrestrial nitrogen feedbacks may accelerate future climate change, Geophys. Res. Lett., 37, L01401, doi:10.1029/2009GB003521, 2010.

Zhang, W., Miller, P. A., Smith, B., Wania, R., Koenigk, T., and Döscher, R.: Tundra shrubification and tree-line advance amplify arctic climate warming: results from an individual-based dynamic vegetation model, Environ. Res. Lett., 8, 034023, doi:10.1088/1748-9326/8/3/034023, 2013. 